DOI: https://doi.org/10.31933/dijdbm.v2i1 Received: $1{ }^{\text {th }}$ October 2020, Revised: $15^{\text {th }}$ November 2020, Publish: $10^{\text {th }}$ December 2020

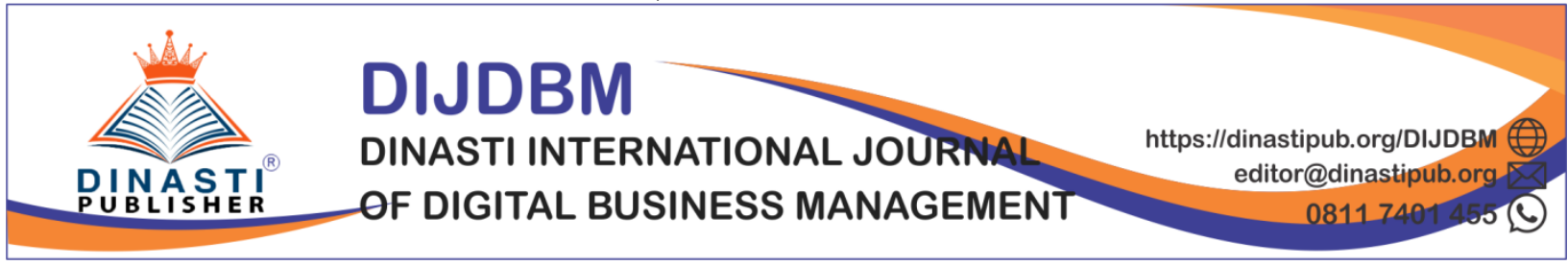

\title{
THE IMPACT OF LEADERSHIP STYLE AND ORGANIZATIONAL CULTURE TOWARDS PLAYER PERFORMANCE THROUGH PLAYER'S WORK SATISFACTION AT BINTANG PRATAMA BASKETBALL CLUB
}

\author{
Stefan Ch. Iskandar Jurgensen ${ }^{1}$, Singmin Johanes Lo ${ }^{2}$ \\ ${ }^{1)}$ Mercu Buana University, Jakarta, jurgensen_13@gmail.com \\ ${ }^{2)}$ Mercu Buana University, Jakarta, singmin.johanes@ mercubuana.ac.id \\ Coresponding Author: Stefan Ch. Iskandar Jurgensen
}

\begin{abstract}
This research purpose way to explored those influence from leadership style towards performance and players' work satisfaction at Bintang Pratama Basketball Club. These research method used quantitative approach. Population and sample were 108 respondents whose members of the club. Data analysis method in this research used Structural Equation Modeling (SEM) with assist of SmartPLS version 3.0 software. The research results indicated that leadership style has a positive and significant impact towards player performance. The leadership style has proven to have a positive and significant influence over the player's work satisfaction. Organizational culture has proven not to have a positive and significant influence towards player performance. Organizational culture has proven to have a positive and significant control across players' work satisfaction. Player's work satisfaction has proven to have a positive and significant control over player performance. Work satisfaction has been shown to mediate the influence of leadership style towards player performance. Work satisfaction has proven to mediate those influence from organizational culture towards player performance.
\end{abstract}

Keywords: Leadership Style, Organizational Culture, Work Satisfaction, Player Performance.

\section{INTRODUCTION}

In these globalization era, The competition in organization especially basketball clubs, is getting higher and more complex so every club is required to improve all things related to each organization and be more responsive in order to survive and continue to develop, those especially in human resources. Human resources in an organization inseparable from each individual performance. The performance of club members or players could be influenced by various factors, including leadership style and organizational culture. Whereas leadership style and organizational culture have an control over the behavior of players in organization. In Efforts to improve player performance beside to control an internal of leadership styles were also need to concern. A leader / trainer needs to provide more attention to leadership style in 
process of influencing, leading the group members activities5 and coordinating the members and organizational goals so both could be achieved.

Apart from this leadership style, the club's success in achieving its goals was also part of organizational culture influence. In an organization, these patterns, norms, beliefs and values would impact these actions or behavior of human resources or club members in organization or club so they would have implications towards players performance in organization or club. With an understanding of tasks that needs to carried out and those understanding towards characteristics of theirs subordinates / players, a leader / coach will be able to provide guidance, encouragement and motivation to all members to achieve the goals. If this interaction process were successful, then they would gain their own satisfaction while improving their own performance, including all Bintang Pratama Basketball Club members. According to data obtained, Bintang Pratama Basketball Club has won various awards in the last 3 years. However, based on the interview results with the manager who is also the owner of Bintang Pratama Basketball Club, Mr. Ali, he explained that the main target of the team which being prepared was to win the Perbasi Cup for each of category, this was because in 2018 and 2019, Bintang Pratama Basketball Club did not succeed in winning the event. Several empirical studies related to the influence of leadership style and organizational culture towards work satisfaction and employee performance have been carried out by several previous research including Harahap (2016) who found that there is no positive influence of organizational culture on employee performance, but leadership style has a positive influence towards it. There is a partially positive influence from work satisfaction on employee performance. There is a partially positive influence of organizational culture on work satisfaction. And There is a partially positive influence of leadership style on work satisfaction.

Meanwhile, Prahasti and Wahyono (2019) found that there was a positive and significant influence on leadership style and organizational culture on work satisfaction and employee performance and work satisfaction also had a significant positive influence on employee performance. But there were differences from Hendriyaldi's research (2019) which found that there was no significant positive influence between leadership style on employee performance, there was a significant positive influence on organizational culture on employee performance. Furthermore, Rasal (2015) found that leadership style, organizational culture and work satisfaction together were capable of giving partially significant influence on employee performance, work satisfaction has a dominant influence on employee performance. The same result was also found by Yunarsih (2017) which defined that leadership style and organizational culture had a significant positive influence over work satisfaction and employee performance. However, different results were found by Prabowo and Irawanto (2017) who argues that leadership style did not have a substantial positive impact on top of work satisfaction and employee performance.

Results from some of research above show that theres still have large enough research gap, this could be seen from the inconsistent results between one researcher to another, where some of them stated that leadership style and organizational culture has a significant positive 
influence on work satisfaction and employee performance, but on the other hand there are some of researchers who notice leadership style and organizational culture did not have effect towards work satisfaction and employee performance.

Based on these description above, the authors were interested in carried out a research which tittle "The Impact of Leadership Style and Organizational Culture on Players Performance Through Player's Work Satisfaction at Bintang Pratama Basketball Club".

\section{LITERATURE REVIEW}

\section{Leadership Style}

Leadership styles are various patterns of behavior favored by leaders in process of directing and influencing followers (Suwatno \& Donni, 2016). Suwatno \& Donni (2016) added that effective leaders are leaders who are great in two dimensions of leadership, namely leadership that is task-oriented and leadership which oriented towards human relations.

\section{Organizational Culture}

Work integrity could be described as specifically related to the way people think, which directs how they act (Rafiie, Azis and Idris, 2018). While organizational culture is the social glue which given to organizational members into characteristics or personalities that vary from one person to another and can be incorporated into the strength of the organization (Rantesalu, Mus, Mapparenta, 2016). Robbins \& Judge (2016) added that organizational culture is a system run by an organization which makes it different from other organizations.

\section{Work Satisfaction}

Work satisfaction is a form of feelings and expressions of employees towards work itself. According to Rafiie, Azis and Idris (2018), actually work satisfaction is individual, and each individual will have a different level of satisfaction according to the values which ruled on him. This occurs because there are differences in each individual, the more aspects of work fill the desires of individual, the higher the level of satisfaction will obtain and it does conversely.

\section{Conceptual Framework}

Based on some research results above, the researchers went investigated and enhanced the employee performance that influenced by leadership style, organizational culture and employee work satisfaction. Based on this description, the theoretical framework in this research could be described as follows: 


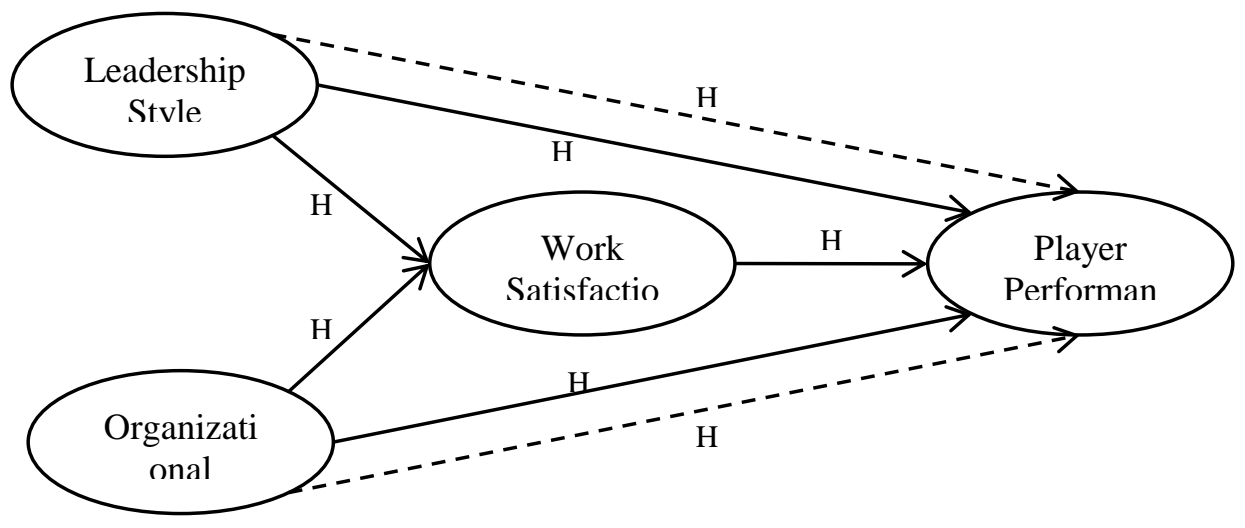

Figure 1.Theorectical Framework

\section{Hypothesis}

These following statements were the hypothesis in this research such as:

H1: Leadership style has a positive impact towards player performance.

H2: Leadership style has a positive influence towards work satisfaction.

H3: Organizational culture has a positive influence on player performance.

H4: Organizational culture has a positive impact on work satisfaction.

H5: Work satisfaction has a positive domination of player performance.

H6: Leadership style has a positive control across player performance through work satisfaction.

H7: Organizational culture has a positive response over player performance through work satisfaction.

\section{RESEARCH METHODS}

This research used quantitative approach with an explanative or causal design that aims to explain how one variable affects or responsible for changes in other variables (Cooper and Schindler, 2014: 141). Furthermore, this research include in cross-sectional research, which is a type of research that collects information / questionnaires only once at a time for a sample. Meanwhile, there are two independent variables in this research, namely transformational leadership, organizational culture and two dependent variables, namely work satisfaction and player performance. The population and sample were 108 respondents who are members of Bintang Pratama basketball club. The data analysis method used Structural Equation Modeling (SEM) with assistance of SmartPLS version 3.0 software to measure the intensity of each research variable and its structural model analyzes these data and research hypothesis.

\section{RESULTS AND DISCUSSION}

\section{Analisis Deskriptif Responden}




\section{Descriptive Analysis of Respondents}

Based on the characteristics of 108 respondents, it was found that male and female respondents were balanced (50\%) with the age category of $14,16,18$, senior. The majority of respondents have a membership period of $>1$ year $(54.6 \%)$. This illustrated that the respondents already know deeply about those cultures which exist in Bintang Pratama Basketball Club. Then they also understood the coach characteristics and the target sets.

\section{Outer Model Measurement}

Based on convergent validity analysis, it was found that all indicators in these research variables (leadership style, organizational culture, work satisfaction and player performance) had loading factor value between 0.706 to 0.896 , so it could be said that it was valid (>0.7).

Based on these coefficient value of Cronbach's alpha and composite reliability for the variables of leadership style, organizational culture, work satisfaction and player performance had value between 0.896 to 0.960 , so it could be said that it was reliable (>0.7).

\section{Inner Model Measurement}

The path coefficients were calculated by SmartPLS bootstrap and the results are shown in Table 1 below.

Table 1. Path Coefficient value and P-Values (Direct and Indirect Influences)

\begin{tabular}{|c|c|c|c|c|c|}
\hline Connection between constructs & $\begin{array}{l}\text { Original } \\
\text { Sample } \\
\text { (O) }\end{array}$ & $\begin{array}{c}\text { Sample } \\
\text { Mean } \\
\text { (M) }\end{array}$ & $\begin{array}{l}\text { Standard } \\
\text { Deviation } \\
(\mathrm{STDEV})\end{array}$ & $\begin{array}{l}\text { T Statistics } \\
(|\mathrm{O} / \mathrm{STDEV}|)\end{array}$ & P Values \\
\hline Leadership Style $\rightarrow$ Player Performance & 0,178 & 0,178 & 0,048 & 3,736 & 0,000 \\
\hline $\begin{array}{lllll}\text { Leadership } & \text { Style } & \rightarrow & \text { Player's } & \text { Work } \\
\text { Satisfaction } & & & & \\
\end{array}$ & 0,305 & 0,310 & 0,098 & 3,104 & 0,002 \\
\hline $\begin{array}{llll}\text { Organizational } & \text { Culture } & \rightarrow & \text { Player } \\
\text { Performance } & & & \end{array}$ & 0,550 & 0,554 & 0,064 & 8,569 & 0,000 \\
\hline $\begin{array}{l}\text { Organizational Culture } \rightarrow \text { Players Work } \\
\text { Satisfaction }\end{array}$ & 0,648 & 0,644 & 0,095 & 6,801 & 0,000 \\
\hline Kepuasan Kerja $\rightarrow$ Player Performance & 0,270 & 0,267 & 0,073 & 3,701 & 0,000 \\
\hline $\begin{array}{l}\text { Leadership } \underset{\text { Style }}{\rightarrow} \rightarrow \text { Player's } \\
\text { Satisfaction } \rightarrow \text { Player Performance }\end{array}$ & 0,082 & 0,082 & 0,033 & 2,466 & 0,014 \\
\hline $\begin{array}{l}\text { Organizational Culture } \rightarrow \text { Player's Work } \\
\text { Satisfaction } \rightarrow \text { Player Performance }\end{array}$ & 0,175 & 0,172 & 0,057 & 3,067 & 0,002 \\
\hline
\end{tabular}

The path coefficient result in Table 1 shows that: leadership style had significant and positive influence on player performance and player work satisfaction; Organizational culture 
had significant and positive control over player performance and player work satisfaction. However, the path analysis results show that the indirect effect of leadership style and organizational culture towards players performance through mediating role of player's work satisfaction was smaller than the direct effect.

\section{$\mathbf{R}^{2}$ Evaluation, F-Test, and Goodness of Fit (GoF) Index}

$\mathrm{R}^{2}$ value result was 0.848 of player work satisfaction variable and 0.925 of player performance variable. The $\mathrm{R}^{2}$ value indicated that the persistence level of exogenous variables (leadership style and organizational culture) towards endogenous variables was quite high.

The performance validation for these combined inner models and outer models (GoF) was 0.787 . According to these results, it could be said that I was good because the Goodness of Fit Index (GoF) value is more than 0.36 (a large score for GoF).

\section{Discussion}

The results from hypothesis test shows that leadership style is proven to have a significant positive influence on the player performance at Bintang Pratama Basketball Club. These results support the research by Prahasti and Wahyono (2019), and Harahap (2016) who found that leadership style has a significant positive influence on performance. This result implies that the management of Bintang Pratama Basketball Club needs to have a coach who has a vision which can spur player performance, a coach who can make players think about a new perspective from matters and could make players feel comfortable when they are close to him and would make players proud to hang out with their coach.

Hypothesis test results show that leadership style was proven has a significant positive impact on work satisfaction of the players at Bintang Pratama Basketball Club. These results supported the research of Prahasti and Wahyono (2019), Rasal (2015), and Haggai (2018) who found that leadership style has a significant positive influence over work satisfaction. In increasing work satisfaction at Bintang Pratama Basketball Club, the management needs to create comfortable feelings for their players when they are close to the coach and proud to hang out with him. This hopes to increase their work satisfaction.

These hypothesis test results show that organizational culture has a significant positive influence towards player performance at Bintang Pratama Basketball Club. These results were in line with Prahasti and Wahyono (2019), Hendriyaldi (2019), and Haggai (2018) who found that organizational culture has a significant positive effect against employee performance.

These hypothesis examine result shows if organizational culture has a significant positive influence towards work satisfaction at Bintang Pratama Basketball Club. These results was supported by research from Prahasti and Wahyono (2019) and Rasal (2015) which defined that there was a partially positive influence from organizational culture towards work satisfaction. This result implies that the management of Bintang Pratama Basketball Club needs to motivate their players to devote all their abilities to practice. And management also need required to be able to work together without feeling suspicious of each other, conduct the daily meeting 
(briefings \& evaluations) in a timely manner and create a boarder towards people's personal lives because it is their own business and all members are open to others. Thus, the level of work satisfaction could be increased.

These hypothesis test results show that work satisfaction has a significant positive effect towards player performance at Bintang Pratama Basketball Club. These results were in line with Prahasti and Wahyono (2019) and Harahap (2016) which found that work satisfaction has a significant positive impression about performance. These results have suggestion that the management of Bintang Pratama Basketball Club needs to provide rewards according to players expectations, in creating a comfortable training atmosphere those players need to enjoy the training with other club members and also the coach should give support to the players.

These hypothesis test result shows if work satisfaction has proven to mediate the influence of leadership style on player performance at Bintang Pratama Basketball Club. These results were supported by the research of Prahasti and Wahyono (2019) and Harahap (2016) which found that there has a mediated impact satisfaction between leadership styles towards performance. The direct and indirect effect test results proved that work satisfaction could mediate the influence of organizational culture and leadership style towards player performance. These results has implications on Bintang Pratama Basketball Club which defined that one of efforts to improve player performance is concern to the level of work satisfaction as a mediate factor of the leadership style, especially in the aspects of the amount of reward that received by players, the coach's attention to the players and coach's comfortness as friends in the club.

Hypothesis test results show that work satisfaction has proven could mediate the influence from organizational culture on player performance at Bintang Pratama Basketball Club. These results were in line with Prahasti and Wahyono research (2019) and Haggai (2018) that discovered if work satisfaction could intervene the influence of organizational culture towards performance. This result has implications to Bintang Pratama Basketball Club that in efforts to improve the player performance need directly focused on organizational culture, specifically in player serious aspect in devoting all their abilities to practice, attend daily meetings (briefings \& evaluations) in a timely manner and create mutual trust to each club members.

\section{CONCLUSION AND SUGGESTION}

\section{Conclusion}

Based on these research results and discussion that have been described in the previous chapter, it could be concluded that: Leadership Style was proven to have a positive and significant effect towards Performance of Bintang Pratama Basketball Club Players; Leadership Style was proven to have a positive and significant strength in the work Satisfaction of Bintang Pratama Basketball Club Players; Organizational Culture has positive and significant control across the Performance of Bintang Pratama Basketball Club Players; 
Organizational Culture has proven to have a positive and significant influence towards work Satisfaction of Bintang Pratama Basketball Club Players; Player work Satisfaction has proven to have a positive and significant effect on the Performance of Bintang Pratama Basketball Club Players; work Satisfaction was proven to mediate the influence from Leadership Style on the Performance of Bintang Pratama Basketball Club Players; and work Satisfaction was proven to mediate the influence of organizational culture towards the Performance of Bintang Pratama Basketball Club Players.

\section{Suggestion}

Based on these conclusions of the research results, the suggestions that could be made to management and further research as follows:

\section{For Organizational Management}

Based on these research results, it is proven that leadership style has a significant positive impact towards work satisfaction and player performance. Thus it is suggested that Bintang Pratama Basketball Club management or basketball club hired a coach who has a vision that could press the player performance and driven players to see something with a new perspective and create comfortable feeling when they are close to the coach and make them proud by hang out with the coach.

Organizational culture has proven to have a significant positive impact towards work satisfaction. Thus, it is suggested that management of Bintang Pratama Basketball Club needs to motivate their players to devote their abilities to practice. And management were also required to be able to work together without feeling suspicious of each other, attend the daily meeting (briefings \& evaluations) in a timely manner and leave people's personal lives as their own business, and members are open to others. Thus, those levels of work satisfaction could be increased.

\section{For Further Research}

1) Further researchers need to add other variables that have an impact towards employee commitment to organization, because in this research by this $7.5 \%$ of performance variables were influenced by other variables outside the research model. Then for the next further research could adding other independent variables such as work discipline, work environment and commitment

2) The next researcher need to use a different research object because this research was only conducted at Bintang Pratama Basketball Club.

3) Research sample which recommended to use is a larger sample so the results that obtained would be more accurate.

\section{REFERENCES}

Cooper, D. R, dan Schindler, P. S. (2014). Business Research Methods. New York: McGrawHill Education. 
Harahap, Insan Harapan. (2016). Pengaruh Budaya Organisasi dan Gaya Kepemimpinan Terhadap Kinerja Melalui Kepuasan Kerja Karyawan Administratif Perguruan Tinggi (PT) XYZ. Jurnal Kenegaraan, 1(1).

Hendriyaldi. (2019). Pengaruh Gaya Kepemimpinan dan Budaya Organisasi Terhadap Kinerja Pegawai. Jurnal Benefita, 4(1).

Prabowo, T. S., Noermijati, N., \& Irawanto, D. W. (2018). The influence of transformational leadership and work motivation on employee performance mediated by job satisfaction. Jurnal Aplikasi Manajemen, 16(1), 171-178.

Prahasti, Shella., \& Wahyono. (2019) Pengaruh Gaya Kepemimpinan, Budaya Organisasi, dan Lingkungan Kerja terhadap Kinerja Pegawai dengan Kepuasan Kerja Sebagai Mediator. Economic Education Analysis Journal, 7(2), 543-552.

Rafiie, Desi Saputra., Azis, Nasir., dan Idris, Sofyan. (2018). Pengaruh Kompetensi, Gaya Kepemimpinan, Budaya Kerja Dan Lingkungan Kerjaterhadap Kepuasan Kerja Pegawai Dan Dampaknya Terhadap Kinerja Pegawai Kantor Kementerian Agama Kabupaten Aceh Barat. Jurnal Magister Manajemen Fakultas Ekonomi dan Bisnis Unsyiah, pp. 3645.

Rasal, Amrullah. (2015). Pengaruh Gaya Kepemimpinan dan Budaya Organisasi Terhadap Kepuasan Kerja Pegawai di Dinas Pendapatan Kota Batam. Jurnal Dimensi, 1(1).

Rantesalu, A., Mus, A. R., Mapparenta, Arifin, Z. (2016). The Effect of Competence, Motivation And Organizational Cultue on Employee Performance: The Mediating Role of Organizational Commitment. Journal of Research in Business and Management, 4(9), 08-14.

Robbins, S. P., \& Judge, T. (2016). Essentials of Organizational Behavior. 14th edition. New Jersey: Pearson Education, Inc.

Setiaji, P. R., \& Lo, S. J. (2020). The Effects of Employees Work Stress and Work Discipline on the Performance of Employees Mediated by Organizational Citizenship Behaviour (OCB) (Case Study: PT Bank "X", Tbk). Dinasti International Journal of Digital Business Management, 1(3), 315-327.

Suwatno dan Donni J, P. 2016. Manajemen SDM dalam Organisasi Publik dan Bisnis. Bandung: Alfabeta.

Yunarsih, Ni Komang. (2017). Pengaruh Gaya Kepemimpinan dan Budaya Organisasi Terhadap Kinerja Pegawai Melalui Mediasi Kepuasan Kerja pada Dinas Pekerjaan Umum Provinsi Bali. JAGADHITA: Jurnal Ekonomi \& Bisnis, 4(1), 72-82. 